\section{Effect of a 12-Week Off-Season Strength Training Program on Athletic Performance in Adolescent Baseball Players}

\author{
Steven F DeFroda ${ }^{1 *}$, Steven J Staffa ${ }^{2}$, Tom Dubuque ${ }^{3}$, Dan \\ Bien $^{3}$, Craig Demers ${ }^{4}$ and Peter K Kriz ${ }^{1,5}$
}

${ }^{1}$ Department of Orthopaedic Surgery, Brown University, Warren Alpert School of Medicine, Providence, RI, USA

${ }^{2}$ Department of Anesthesiology, Critical Care and Pain Medicine, Harvard Medical School, Boston Children's Hospital, Boston, Massachusetts, USA

${ }^{3}$ Department of Physical Therapy, University Orthopedics, Providence, RI, USA

${ }^{4}$ Roger Williams University, Providence, RI, USA

${ }^{5}$ Division of Sports Medicine, Departments of Orthopedics and Pediatrics, Warren Alpert Medical School, Brown University, Rhode Island Hospital/ Hasbro Children's Hospital, Providence, Rhode Island, USA

\begin{abstract}
Purpose: Off-season strength training programs have become common place in baseball, as a means to improve athletic performance and reduce injury risk. No study has assessed analytics and advanced metrics during the season following an off-season, baseball-specific strength training program. We hypothesized that players completing a 12-week baseball-specific strength and conditioning program would experience significant gains in running speed and bat exit velocity, as well as in-season hitting performance metrics.

Methods: 25 healthy high school baseball players were recruited into an intervention group. 60-yard dash and batting exit velocity were measured pre-program. The intervention group then performed an off-season 12-week strength training program, with measurements repeated post-program. Hitting performance metrics were assessed in the subsequent baseball season, utilizing a comparison group of teammates who did not perform the program. Changes from baseline were evaluated using paired t-tests within, and the training effect was assessed using repeated-measures analysis of variance to as-
\end{abstract}

${ }^{\star}$ Corresponding author: Steven F DeFroda, Department of Orthopaedic Surgery, Brown University, Warren Alpert School of Medicine, Providence, RI, USA Tel: +1 4014444030; E-mail: SDEFRODA@gmail.com

Citation: DeFroda SF, Staffa SJ, Dubuque T, Bien D, Demers C, et al. (2020) Effect of a 12-Week Off-Season Strength Training Program on Athletic Performance in Adolescent Baseball Players. Sport Med Inj Care 2: 009.

Received: November 11, 2020; Accepted: December 04, 2020; Published: December 11, 2020

Copyright: (C) 2020 DeFroda SF, et al. This is an open-access article distributed under the terms of the Creative Commons Attribution License, which permits unrestricted use, distribution, and reproduction in any medium, provided the original author and source are credited. sess differences in changes between the intervention and the control groups. A two-tailed significance level was set at $P<0.05$.

Results: Running speed showed a statistically significant improvement $(0.278$ seconds average reduction; $95 \% \mathrm{Cl} 0.161,0.394 ; P<$ $0.001)$ while bat exit velocity did not $(0.476 \mathrm{mph}$ average gain; $95 \%$ $\mathrm{Cl}-1.267,2.219 ; P=0.575)$. There was no statistically significant change in hitting performance among the intervention group in the season following the program when compared to the season immediately preceding the program. No statistically significant changes in hitting performance statistics were observed when comparing intervention players versus the comparison group. No participants were injured at any time during the study.

Conclusion: Performing a 12-week strength training program increased running speed but not bat exit velocity or post-program hitting performance statistics. Baseball-specific strength training programs are safe and effective interventions that can improve athleticism in adolescents.

Keywords: Baseball; Injury risk; Performance; Strength training

\section{Introduction}

Strength, power, speed, and agility are key elements of a baseball player's athletic performance. Like most youth sports, baseball has become a three-season sport, with players often playing 50-60 game summer schedules in addition to their high school seasons as more youth athletes trend towards early specialization [1]. With this early specialization, however, comes an increased risk of overuse injury. Pasulka et al., examined 1,190 youth athletes age 7-18 and found that $26 \%$ were single-sport specialized; defined as participating in a single sport for greater than 8 months of the year [1]. Additionally, single-sport athletes were more prone to overuse injury than other athletes, $44.3 \%$ versus $32.2 \%$ [1]. Equally concerning as the trend in youth sport specialization is the temporal trend of youth muscular fitness (i.e., muscular strength, power and endurance) which indicates that today's youth are weaker and slower than previous generations [2]. Young athletes who do not address neuromuscular deficits and build strength reserves may be more likely to suffer a sports-related injury and less likely to attain elite-level performance [2-4].

One key to combating injury in youth sports could be proper off-season conditioning, both to allow for recovery, promote movement variability and competence, build musculoskeletal capacity and resilience, and to promote muscle memory for future seasons. Off-season strength and conditioning programs have become popular in baseball, as a means to improve athletic performance as well as reduce injury risk. Significant variability exists in baseball-specific training, ranging from resistance training (weightlifting, resistance band and medicine ball workouts, plyometrics) to interval throwing programs to weighted ball throwing [5-7]. Previous studies have demonstrated that lower body power, upper body power, and torso rotational power are correlated to bat swing velocity in adolescent, high school (HS), and college baseball players. Similarly, throwing velocity increases have been demonstrated in HS baseball players that have completed baseball-specific 4-week training programs involving 
resistance training [8]. More recently, studies involving weighted ball throwing programs have demonstrated increased pitch velocity following a 6-week program in adolescent pitchers, but at the cost of an increased injury rate (24\% injury rate in experimental group vs. $0 \%$ in control group) [7]. No current studies have assessed analytic improvements in performance following an off-season, baseball-specific strengthening and conditioning program.

The purpose of our study was to prospectively investigate the effects of 12-week strength and conditioning program on certain sport-specific performance metrics on HS baseball athletes. We hypothesized that athletes participating in strength and conditioning workouts will experience significant improvements in showcase metrics (e.g., 60-yard dash times, batting exit velocity) as well as hitting performance measures in their post-program seasons.

\section{Methods}

\section{Subjects}

HS baseball players between the ages of 14 and 18 years were recruited for the study during the off-season. Players was excluded if they had a current injury which precluded participation in the program. A total of 25 male baseball players from HS teams within a 50mile radius of Providence, RI met these criteria and agreed to participate. Each participant completed intake forms consisting of medical history, prior experience with strength and conditioning and baseball background. Participants under 18 years of age provided written assent and their legal guardians provided informed consent. The subjects' mean (standard deviation) age, weight, and height were 15.4 (1.0) years, $73.2(10.3) \mathrm{kg}$, and $174.4(4.2) \mathrm{cm}$, respectively. Years of baseball experience were 9.7 (1.5).

A comparison group of $15 \mathrm{HS}$ baseball players between the ages of 14 and 18 years from one of the local high schools and one of the regional travel teams was created to compare in-season performance metrics. Members of the comparison group were teammates of the participants but did not participate in the program and did not complete pre-/post-program performance measures (e.g., 60-yard dash, batting exit velocity). Participants under 18 years of age provided written assent and their legal guardians provided informed consent. Anthropometric data (weight in $\mathrm{kg}$, height in $\mathrm{cm}, \mathrm{BMI}$ ) were collected prior to program participation utilizing a physician scale (Henry Schein Model 1127157, Melville, NY).

A 12-week strength and conditioning program was developed collaboratively by fellowship-trained sports medicine specialists and certified physical therapists utilizing established strength and conditioning references (Appendix 1) [9-11]. The 12-week duration was determined based on previously published literature regarding off-season strength and conditioning programs in this age group $[5,12]$. Athletes were to complete workouts twice a week under the direct supervision of certified physical therapists and sports medicine physicians, and once a week on their own. All athletes were given a "workout log" to track their workouts and promote compliance; this notebook included video links to the various exercises so participants could review proper form and technique (Appendix 2).

A showcase-type setting on a HS varsity baseball field (grass surface) was utilized to collect pre-program performance data on September 16, 2018. Post-program data was collected on December 17, 2018 at a university field house which included an indoor batting cage and synthetic surface indoor track. Participants performed a dynamic warm-up prior to data collection. Participants designated their primary and secondary positions, and were grouped according to the following positions: infield, outfield, pitcher, catcher. Average length of time from completion of the program to the beginning of the HS baseball season for most participants was 12 weeks.

\section{Bat Exit Velocity}

Participants designated their individual preference of bat material [e.g., wood, metal (alloy, composite)] which was recorded. Participants used the same bat for pre- and post-program data collection. All alloy and composite bats were Bat-Ball Coefficient of Restitution (BBCOR) certified. After performing warm-up swings on a tee, participants faced live pitching in a batting cage from an adult baseball coach who threw fastballs behind an L-screen. Bat exit velocities from 10 swings were recorded using a handheld radar gun (Pocket Radar Model PR1000, Santa Rosa, CA) situated 5 feet behind the hitter outside the cage. The best effort (mph) was utilized.

\section{0-yard dash}

Participants performed pre-program 60-yard dashes on the grass in foul territory along the first base side of the field. Distances were measured using an open reel measuring tape. Cones were used to demarcate the start and finish lines. Participants ran the distance one at a time, and times were recorded using a stopwatch, with recordings to the 100th of a second. Hand signals were used to start the heat, and a researcher recorded the participants' times at the finish line. Post-program 60-yard dashes were performed on a synthetic indoor track in a university field house. An identical protocol was used to measure/ demarcate distances and times.

\section{In-Season performance metrics}

All participants consented to allow researchers to access their 2018 and 2019 GameChanger ${ }^{\mathrm{TM}}$ statistics from their HS(varsity, JV) and summer (travel, American Legion) seasons, which were their baseball seasons immediately before and after the strength and conditioning program. GameChanger ${ }^{\mathrm{TM}}$ is a free mobile app and website (https://gc.com) that provides scorekeeping, advanced statistics, and live game updates for baseball teams and their fans. For the HSand summer seasons, the participant's primary team's statistical data was used (e.g., varsity OR JV for HS, travel OR American Legion for summer). The comparison group's in-season performance metrics were manually compiled from publicly available box scores available in GameChanger ${ }^{\mathrm{TM}}$. Intervention group and comparison group players with at least 20 plate appearances in both 2018 and 2019 with retrievable data in GameChanger ${ }^{\mathrm{TM}}$ were included in the analysis.

\section{Statistical analysis}

All data were collected and analyzed using SPSS (version 25, IBM Corporation, Armonk, NY) and Stata (version 15.0, StataCorp LLC, College Station, TX).All continuous data were confirmed as adhering to a normal (Gaussian) distribution using the Shapiro-Wilk test and histogram visualization within each group and presented using means and standard deviations. Paired t-tests were performed to evaluate changes from baseline in bat exit velocity, 60-yard dash time and in-season performance metrics. The training effect was assessed using repeated-measures analysis of variance to assess differences in seasonal changes (deltas) between the intervention and the control groups. Changes in continuous outcomes were presented with $95 \%$ confidence intervals and $\mathrm{P}$ values. A two-tailed significance level was set a priori at $\mathrm{P}<0.05$. 
Citation: DeFroda SF, Staffa SJ, Dubuque T, Bien D, Demers C, et al. (2020) Effect of a 12-Week Off-Season Strength Training Program on Athletic Performance in Adolescent Baseball Players. Sport Med Inj Care 2: 009.

\section{Results}

A total of $25 \mathrm{HS}$ players participated in the program. Of the 25 participants, 19 players $(76 \%)$ completed $\geq 75-90 \%, 3$ players $(12 \%)$ completed $\geq 50-74 \%$, and 3 players completed $\geq 25-49 \%$ of the supervised training sessions. 20 players completed pre- and post-program 60 -yard dashes, and 21 players completed pre- and post-program batting exit velocities. No participants reported any injuries at any time during the study. Pre- and post-program performance measures among the participants are shown in table 1 . Running speed showed a statistically significant change $(0.278$ seconds average reduction; $95 \%$ CI $0.161,0.394 ; \mathrm{P}<0.001)$ while bat exit velocity did not $(0.476$ mph average gain; $95 \% \mathrm{CI}-1.267,2.219 ; \mathrm{P}=0.575$ ).
No statistically significant changes in hitting metrics were observed for the comparison group in the season following the strength training program compared to the season prior to the program.

Hitting performance metrics were evaluated between the intervention group and the comparison group (Table 4). No statistically significant changes in BA, OBP, SLG, or OPS were observed between these groups in the season prior to and following the strength training program. Figure 1 summarizes the hitting performance metrics of the intervention and comparison groups in seasons 2018 and 2019.

\section{Discussion}

A 12-week off-season strength training program for HS baseball players safely and effectively enhanced physical performance with

\begin{tabular}{|c|c|c|c|c|c|c|}
\hline Performance Measure & N & Pre & Post & Change & 95\% CI for Change & P value \\
\hline 60-yard dash (sec) & 20 & $8.085 \pm 0.648$ & $7.807 \pm 0.548$ & 0.278 & $(0.161,0.394)$ & 0.0001 \\
\hline Batting Exit Velocity (mph) & 21 & $74.71 \pm 5.875$ & $75.19 \pm 6.431$ & 0.476 & $(-2.219,1.267)$ & 0.575 \\
\hline
\end{tabular}

Table 1: Pre- and Post-Program Performance Measures among Players with Intervention.

Data are presented using mean \pm standard deviation for each performance measure.

The evaluation of the change in performance measures from pre- to post-program was done using paired t-tests.

Evaluation of change in hitting performance from 2018 and 2019 seasons among players in the intervention group is shown in table 2. Of the 25 participants, 18 players had at least 20 plate appearances in each season with retrievable data in Game Changer ${ }^{\mathrm{TM}}$, which were criteria for inclusion in the analysis. Batting average (BA), on base percentage (OBP), slugging percentage (SLG), and on base plus slugging percentage (OPS) performance statistics were calculated using standard formulas (www.baseball-reference.com). No statistically significant change in hitting metrics was observed for the intervention group in the season following the strength training program compared to the season prior to the program. regards to 60-yard dash times. Also, while a statistically significant increase in bat exit velocity was not found, our study did show an increase in bat exit velocity of nearly half a mile per hour. This slight increase could be the difference between a hard-hit single up the middle and a diving defensive play by a middle infielder resulting in a routine out at first. No injuries were documented during the training process, and no injuries which could be attributed to the training program occurred in the subsequent baseball season. This is important in validating the safety and effectiveness of such a program in order to best develop youth athletes, both with regards to physical performance as well as injury prevention. As single-sport specialization

\begin{tabular}{|c|c|c|c|c|c|}
\hline Hitting Metric & 2018 Season (n=18) & 2019 Season (n=18) & Change & 95\% CI for Change & P value \\
\hline BA & $0.286 \pm 0.018$ & $0.298 \pm 0.066$ & 0.012 & $(-0.027,0.050)$ & $(-0.053,0.030)$ \\
\hline OBP & $0.412 \pm 0.066$ & $0.401 \pm 0.069$ & -0.011 & 0.547 \\
\hline SLG & $0.376 \pm 0.109$ & $0.388 \pm 0.121$ & 0.012 & $(-0.043,0.069)$ \\
\hline OPS & $0.762 \pm 0.204$ & $0.789 \pm 0.168$ & 0.027 & $(-0.086,0.141)$ & 0.63 \\
\hline
\end{tabular}

Table 2: Evaluation of Change in Hitting Performance from 2018 to 2019 among Players with Intervention.

Players with at least 20 plate appearances in both 2018 and 2019 were included in the analysis.

Data are presented using mean \pm standard deviation for each year. The evaluation of the change from 2018 to 2019 was done using paired t-tests.

Hitting performance statistics from 2018 and 2019 seasons were also analyzed among players in the comparison group (Table 3). Of the 15 players in the comparison group, 11 players had at least 20 plate appearances in each season with retrievable data in Game Changer ${ }^{\mathrm{TM}}$. becomes more common among youth athletes, strength training programs that emphasize sport-specific training while allowing adequate recovery from the prior season will be essential. Moreover, our results support the previous claims made by Faigenbaum et al., [2] that

\begin{tabular}{|c|c|c|c|c|c|}
\hline Hitting Metric & 2018 Season (n=11) & 2019 Season (n=11) & Change & 95\% CI for Change & P value \\
\hline BA & $0.240 \pm 0.084$ & $0.264 \pm 0.119$ & 0.024 & $(-0.074,0.122)$ \\
\hline OBP & $0.361 \pm 0.100$ & $0.348 \pm 0.122$ & -0.013 & $(-0.125,0.100)$ \\
\hline SLG & $0.286 \pm 0.111$ & $0.303 \pm 0.141$ & 0.017 & $(-0.106,0.141)$ & $(-0.234,0.234)$ \\
\hline OPS & $0.647 \pm 0.204$ & $0.647 \pm 0.246$ & 0 & 0.759 \\
\hline
\end{tabular}

Table 3: Evaluation in Change in Hitting Performance from 2018 to 2019 among Comparison Group.

Players with at least 20 plate appearances in both 2018 and 2019 were included in the analysis.

Data are presented using mean \pm standard deviation for each year. The evaluation of the change from 2018 to 2019 was done using paired t-tests. 


\begin{tabular}{|c|c|c|c|}
\hline Hitting Metric & $\begin{array}{c}\text { Change among In- } \\
\text { tervention Players } \\
(\mathbf{n}=\mathbf{1 8})\end{array}$ & $\begin{array}{c}\text { Change among } \\
\text { Comparison } \\
\text { Group }(\mathbf{n}=\mathbf{1 1})\end{array}$ & P value \\
\hline BA & $0.012 \pm 0.077$ & $0.024 \pm 0.146$ & 0.761 \\
\hline OBP & $-0.011 \pm 0.084$ & $-0.013 \pm 0.167$ & 0.988 \\
\hline SLG & $0.012 \pm 0.112$ & $0.017 \pm 0.184$ & 0.934 \\
\hline OPS & $0.027 \pm 0.228$ & $0 \pm 0.349$ & 0.797 \\
\hline
\end{tabular}

Table 3: Comparison of Change in Hitting Performance from 2018 to 2019 between Intervention Players vs Comparison Group.

Players with at least 20 plate appearances in both 2018 and 2019 were included in the analysis.

Data are presented using mean \pm standard deviation for each year. The evaluation of the change from 2018 to 2019 was done using paired t-tests.
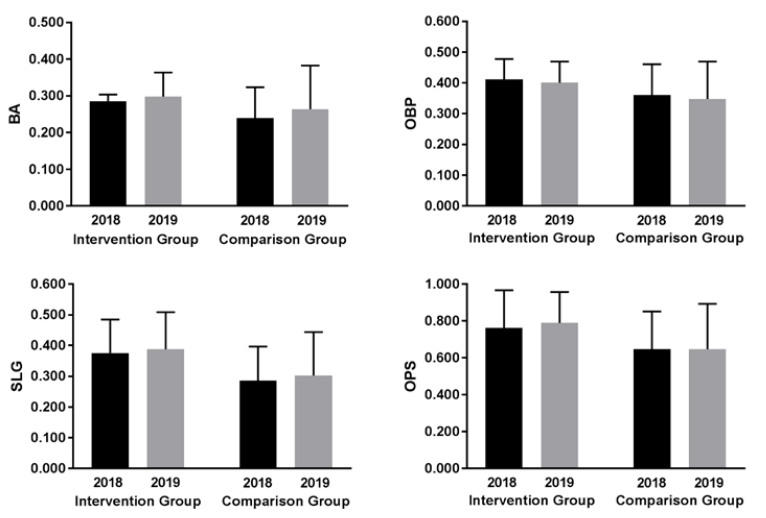

Figure 1: Hitting performance metrics of the intervention and comparison groups in seasons 2018 and 2019.

regular participation in a well-designed youth resistance training program can alter physical activity trajectories, increase muscular fitness, enhance performance and reduce associated injury risks in children and adolescents.

To our knowledge, our study is the first to investigate the effect of an off-season strength training program on performance metrics for athletes using publicly available data, comparing the season immediately prior to the season following the training program, in any organized sport. There are however some studies that examine the short term ability of strength and conditioning programs with regards to maximum velocity $[8,13]$. Escamilla et al., showed an increase in maximum pitching velocity in 11-15 year old athletes following a 4 -week organized conditioning program [8]. The authors noted that this was a short term increase and an association with in-season performance was not investigated. Escamilla et al., performed a similar study in a group of 14-17 year old athletes, which is more consistent with the current study [13]. Three separate 6-week throwing programs, Throwers Ten (TT), Keiser Pneumatic (KP), and Plyometric (PLY), all resulted in a significant increase in throwing velocity compared to the control group [13]. Once again the authors did not examine the effect of the program on injury rates or in-season performance.

With regard to performance, our current study did not demonstrate statistically significant improvement in any of the major offensive statistical categories (BA, OBP, SLG, OPS) for the intervention group versus the comparison group. This could have been due to limitations in sample size in both the study and comparison groups. Additionally, as demonstrated by the aforementioned Escamilla study, 6 physical gains in strength training programs may potentially be short-term and transient in nature. It is possible that athletes whom perform pre-/ off-season strength training programs achieve their peak level of fitness early in the season, as athletic (e.g., games, practices, travel, suboptimal meal schedules), academic (e.g., homework, exams, standardized testing, tutoring), and social (e.g., video games, dating) scheduling during the season interferes with ideal strength and conditioning programming and nutrition/hydration. Consequently, sustaining off-season strength training gains in-season can be very challenging to attain, and inevitably requires an in-season strength training program with modified volume/intensity that can be practical to perform $[14,15]$.

Our study had several limitations. First, participants were not randomized into intervention and control groups. Second, sample size (participant, comparison groups) was limited, and, for this reason, participant and comparison groups were not equal. Additionally, it was our intent to stratify the participant group by the percentage of supervised training sessions they attended (e.g., $\geq 75-90 \%, \geq 50-74 \%$, $\geq 25-49 \%,<25 \%$ ) and compare performance metrics among the four groups. However, a small sample size prevented stratified analysis. Fourth, due to winter weather conditions in the Northeast, we were unable to perform pre- and post-program 60 -yard dash testing and bat exit velocity testing in the same environments. It is possible that the improved mean 60-yard dash times achieved on an indoor synthetic surface could be partially due to differing extrinsic factors. Brechue et al., [16] evaluated 68 National Collegiate Athletic Association (NCAA) Division II college football players to determine the effects of football equipment and running surface on the 40-yard dash times. Running surfaces used included a rubberized indoor track in the field house, and outdoor natural grass game field at the football stadium. Sprint performance was significantly impaired when running on natural grass compared with running on an indoor rubberized track (linemen: $0.15 \pm 0.09$-second increase on grass vs. indoor surface; backs: $0.12 \pm 0.06$-second increase), and the magnitude of the sprint performance impairment was similar between linemen and backs.

While it is likely that the improved sprint performance result in our study was a direct result of surface type, the mean decrease in sprint performance time was 0.278 seconds, the magnitude of change which unlikely can be explained by running surface alone. Even a 0.100 second improvement in 60 -yard dash time in baseball is clinically significant, and can mean the difference between an infield single versus an out, or a stolen base versus caught stealing. Also, with regards to performance and injury we did not perform a longitudinal analysis of performance or injury rate in the study group. As we only have one year's worth of data, it may be truly difficult to determine the cumulative effect that the strength and conditioning program had on performance and injury prevention; this could be improved with further follow up. Additionally, because the training program was completed by December, it is possible that any gains imparted by the program may have been lost by the time the spring season began in March. Finally as with any study of adolescent athletes, it was not possible to determine if physical gains were solely a result of their growth and maturation as the transition to skeletally mature athletes.

\section{Conclusion}

Performing a 12-week strength training program significantly increased running speed but not bat exit velocity or post-program hitting 
Citation: DeFroda SF, Staffa SJ, Dubuque T, Bien D, Demers C, et al. (2020) Effect of a 12-Week Off-Season Strength Training Program on Athletic Performance in Adolescent Baseball Players. Sport Med Inj Care 2: 009

performance statistics. Baseball-specific strength training programs are safe and effective interventions that can improve athleticism in adolescents, and likely result in clinically significant gains in both sprint performance and bat exit velocity. Future research utilizing prospective, randomized controlled trials assessing the effect of combined off-season and in-season strength training programs on baseball-specific metrics (e.g., showcase metrics and in-season advanced metrics for hitting) and injury can provide essential data targeting injury prevention in a single-sport specialization era.

\section{Conflict of Interest}

The authors have no relevant financial disclosures or conflicts to report. No external funding was received for this project.

\section{Appendix 1: Strength and Conditioning Program}

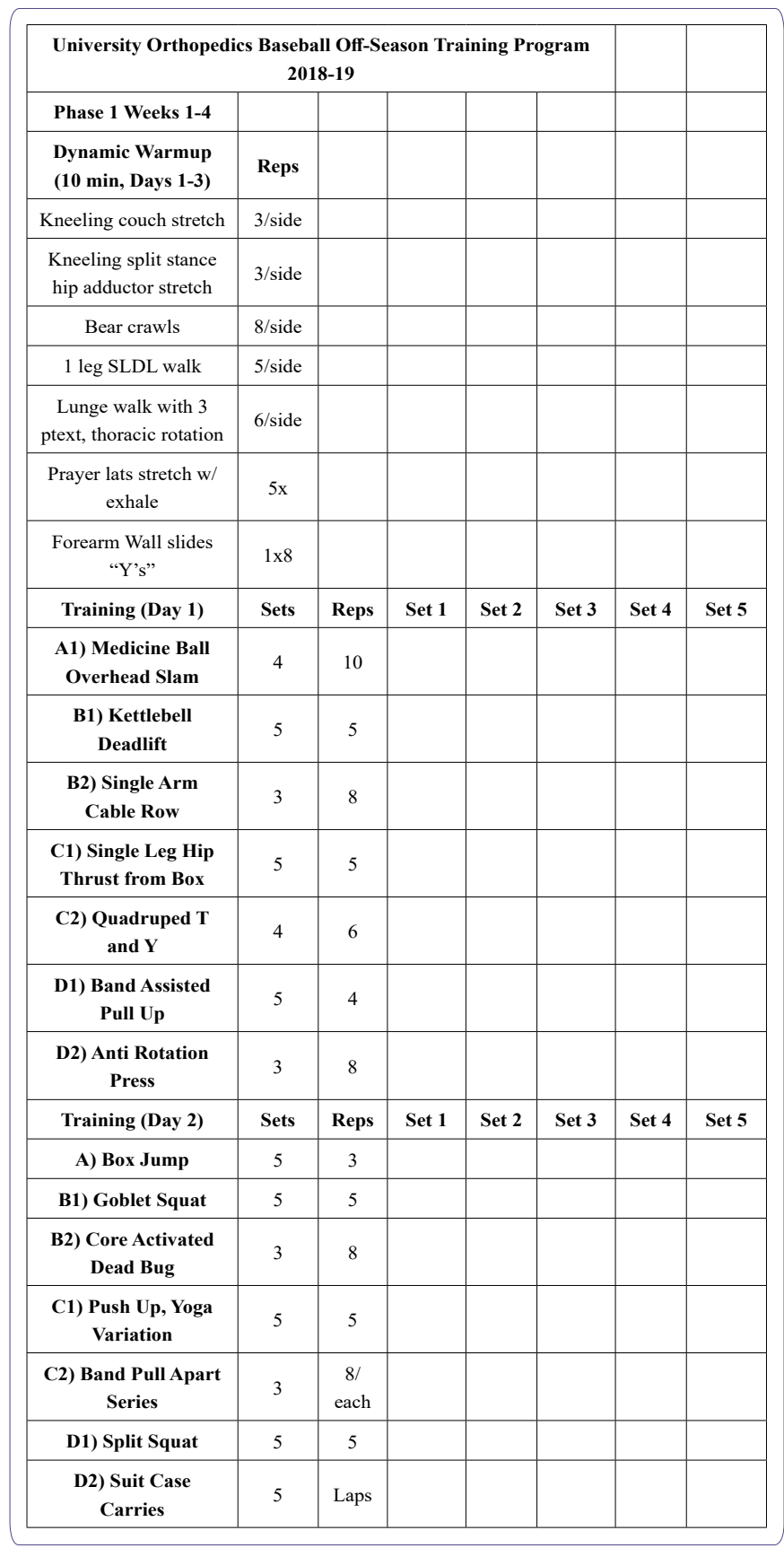

\begin{tabular}{|c|c|c|c|c|c|c|c|}
\hline ESD Sled Push & 5 & Laps & & & & & \\
\hline Training (Day 3) & Sets & Reps & Set 1 & Set 2 & Set 3 & Set 4 & Set 5 \\
\hline A) 25 yard sprint & 10 & 1 & & & & & \\
\hline $\begin{array}{c}\text { B1) Cable Pull } \\
\text { Through }\end{array}$ & 5 & 5 & & & & & \\
\hline $\begin{array}{c}\text { B2) Bear Plank with } \\
\text { Shoulder Tap }\end{array}$ & 3 & 5 & & & & & \\
\hline $\begin{array}{c}\text { C1) Goblet Loaded } \\
\text { Lateral Lunge }\end{array}$ & 5 & 5 & & & & & \\
\hline $\begin{array}{c}\text { C2) Alternating } \\
\text { Dumb Bell Floor } \\
\text { Press }\end{array}$ & 3 & $8 /$ & & & & & \\
\hline D1) SL RDL & 5 & 5 & & & & & \\
\hline $\begin{array}{c}\text { D2) Contralaterally } \\
\text { loaded Step Up }\end{array}$ & 3 & 10 & & & & & \\
\hline
\end{tabular}

\begin{tabular}{|c|c|c|c|c|c|c|c|}
\hline \multicolumn{6}{|c|}{$\begin{array}{l}\text { University Orthopedics Baseball Off-Season Training Program } \\
\qquad 2018-19\end{array}$} & & \\
\hline Phase 2 Week 5-8 & & & & & & & \\
\hline $\begin{array}{c}\text { Dynamic Warm-up } \\
\text { (10 min, Days 1-3) }\end{array}$ & Reps & & & & & & \\
\hline Kneeling couch stretch & 3/side & & & & & & \\
\hline $\begin{array}{l}\text { Kneeling split stance } \\
\text { hip adductor stretch }\end{array}$ & 3/side & & & & & & \\
\hline Bear crawls & 8/side & & & & & & \\
\hline 1 leg SLDL walk & $5 /$ side & & & & & & \\
\hline $\begin{array}{l}\text { Lunge walk with } 3 \\
\text { ptext, thoracic rotation }\end{array}$ & 6/side & & & & & & \\
\hline $\begin{array}{l}\text { Prayer lats stretch } \mathrm{w} / \\
\text { exhale }\end{array}$ & $5 \mathrm{x}$ & & & & & & \\
\hline $\begin{array}{l}\text { Forearm Wall slides } \\
\text { "Y's" }\end{array}$ & $1 \times 8$ & & & & & & \\
\hline Training (Day 1) & Sets & Reps & Set 1 & Set 2 & Set 3 & Set 4 & Set 5 \\
\hline $\begin{array}{l}\text { A1) Med Ball Kneel- } \\
\text { ing Chest Pass/Hip } \\
\text { Hinge }\end{array}$ & 5 & 6 & & & & & \\
\hline $\begin{array}{l}\text { B1) Trap Bar } \\
\text { Deadlift }\end{array}$ & 5 & 5 & & & & & \\
\hline $\begin{array}{l}\text { B2) Bottoms Up KB } \\
\text { Press }\end{array}$ & 3 & 8 & & & & & \\
\hline C1) Pull Up & 5 & 4 & & & & & \\
\hline $\begin{array}{l}\text { C2) Side Plank with } \\
\text { Row }\end{array}$ & 4 & 5 & & & & & \\
\hline $\begin{array}{l}\text { D1) SL RDL with } \\
\text { Cable }\end{array}$ & 5 & 5 & & & & & \\
\hline $\begin{array}{l}\text { ESD Battle Ropes } \\
\text { Circuit }\end{array}$ & 5 & $\begin{array}{l}30 \\
\sec \end{array}$ & & & & & \\
\hline Training (Day 2) & Sets & Reps & Set 1 & Set 2 & Set 3 & Set 4 & Set 5 \\
\hline A) Kettlebell Swing & 5 & 10 & & & & & \\
\hline $\begin{array}{l}\text { B1) Bilateral Kettle- } \\
\text { bell Racked Squat }\end{array}$ & 5 & 5 & & & & & \\
\hline B2) Stir the Pot & 3 & 8 & & & & & \\
\hline C1) Landmine Press & 5 & 5 & & & & & \\
\hline $\begin{array}{c}\text { C2) Band Step Back } \\
\text { @ 90/90 }\end{array}$ & 3 & $\begin{array}{c}8 / \\
\text { each }\end{array}$ & & & & & \\
\hline $\begin{array}{l}\text { D1) Rear Foot Ele- } \\
\text { vated Split Squat }\end{array}$ & 5 & 5 & & & & & \\
\hline
\end{tabular}

Volume $2 \cdot$ Issue $1 \cdot 100009$ 
Citation: DeFroda SF, Staffa SJ, Dubuque T, Bien D, Demers C, et al. (2020) Effect of a 12-Week Off-Season Strength Training Program on Athletic Performance in Adolescent Baseball Players. Sport Med Inj Care 2: 009.

\begin{tabular}{|c|c|c|c|c|c|c|c|}
\hline $\begin{array}{c}\text { D2) Half Kneeling } \\
\text { Cable Chop }\end{array}$ & 3 & 8 & & & & & \\
\hline $\begin{array}{c}\text { ESD Lateral Sled } \\
\text { Drag }\end{array}$ & 5 & Laps & & & & & \\
\hline Training (Day 3) & Sets & Reps & Set 1 & Set 2 & Set 3 & Set 4 & Set 5 \\
\hline $\begin{array}{c}\text { A1) Bench Straddle } \\
\text { Hop }\end{array}$ & 3 & 8 & & & & & \\
\hline $\begin{array}{c}\text { B1) Cable Alternat- } \\
\text { ing Row }\end{array}$ & 5 & 5 & & & & & \\
\hline $\begin{array}{c}\text { B2) Hamstring Curl } \\
\text { with Ball }\end{array}$ & 3 & 8 & & & & & \\
\hline C1) Inverted Row & 5 & 5 & & & & & \\
\hline $\begin{array}{c}\text { C2) Bench Side } \\
\text { Plank }\end{array}$ & 4 & 4 & & & & & \\
\hline D1) Leg Press & 6 & 5 & & & & & \\
\hline $\begin{array}{c}\text { ESD Bike Interval } \\
\text { Circuit }\end{array}$ & & 30 sec sprint, 2 min cruise & & \\
\hline
\end{tabular}

\begin{tabular}{|c|c|c|c|c|c|c|c|}
\hline \multicolumn{6}{|c|}{$\begin{array}{c}\text { University Orthopedics Baseball Off-Season Training Program } \\
\text { 2018-19 }\end{array}$} & & \\
\hline \multicolumn{8}{|l|}{ Phase 3 Week 9-12 } \\
\hline $\begin{array}{l}\text { Dynamic Warm-up } \\
\text { (10 min, Days 1-3) }\end{array}$ & Reps & & & & & & \\
\hline Kneeling couch stretch & 3/side & & & & & & \\
\hline $\begin{array}{l}\text { Kneeling split stance } \\
\text { hip adductor stretch }\end{array}$ & 3/side & & & & & & \\
\hline Bear crawls & 8/side & & & & & & \\
\hline 1 leg SLDL walk & 5/side & & & & & & \\
\hline $\begin{array}{l}\text { Lunge walk with } 3 \\
\text { point ext, thoracic } \\
\text { rotation }\end{array}$ & 6/side & & & & & & \\
\hline $\begin{array}{l}\text { Prayer lats stretch } \mathrm{w} / \\
\text { exhale }\end{array}$ & $5 \mathrm{x}$ & & & & & & \\
\hline $\begin{array}{l}\text { Forearm Wall slides } \\
\text { "Y's" }\end{array}$ & $1 \times 8$ & & & & & & \\
\hline Training (Day 1) & Sets & Reps & Set 1 & Set 2 & Set 3 & Set 4 & Set 5 \\
\hline $\begin{array}{c}\text { A1) Medicine Ball } \\
\text { Crow Hop to Shot } \\
\text { Put }\end{array}$ & 4 & 5 & & & & & \\
\hline $\begin{array}{l}\text { B1) Landmine SL } \\
\text { RDL }\end{array}$ & 5 & 5 & & & & & \\
\hline $\begin{array}{l}\text { B2) Suspension } \\
\text { Trainer Fall Out }\end{array}$ & 4 & 5 & & & & & \\
\hline C1) Step Up & 5 & 5 & & & & & \\
\hline $\begin{array}{l}\text { C2) Cable Row to } \\
90 / 90 \mathrm{ER}\end{array}$ & 4 & 5 & & & & & \\
\hline $\begin{array}{l}\text { D1) Single Arm } \\
\text { Cable Pull Down }\end{array}$ & 3 & 8 & & & & & \\
\hline $\begin{array}{l}\text { D2) Split Stance } \\
\text { Chop }\end{array}$ & 3 & 8 & & & & & \\
\hline $\begin{array}{c}\text { ESD Speed Ladder } \\
\text { Frontal Plane Em- } \\
\text { phasis }\end{array}$ & 5 & laps & & & & & \\
\hline A) Kettlebell Swing & 5 & 10 & & & & & \\
\hline Training (Day 2) & Sets & Reps & Set 1 & Set 2 & Set 3 & Set 4 & Set 5 \\
\hline $\begin{array}{l}\text { A) Medicine Ball } \\
\text { Side Throw }\end{array}$ & 5 & 8 & & & & & \\
\hline
\end{tabular}

\begin{tabular}{|c|c|c|c|c|c|c|c|}
\hline B1) Reverse Lunge & 5 & 5 & & & & & \\
\hline $\begin{array}{c}\text { B2) Side Plank with } \\
\text { Clam }\end{array}$ & 3 & 8 & & & & & \\
\hline C1) Turkish Get Up & 5 & 2 & & & & & \\
\hline C2) X Band Walk & 3 & $\begin{array}{c}8 / \\
\text { each }\end{array}$ & & & & & \\
\hline $\begin{array}{c}\text { D1) Suspension } \\
\text { Trainer Assist Bowler } \\
\text { Squat }\end{array}$ & 5 & 5 & & & & & \\
\hline $\begin{array}{c}\text { D2) Landmine Row } \\
\text { 2) }\end{array}$ & 5 & 5 & & & & & \\
\hline $\begin{array}{c}\text { ESD Speed Ladder } \\
\text { with Sag Plane } \\
\text { Emphasis }\end{array}$ & 5 & Laps & & & & & \\
\hline Training (Day 3) & Sets & Reps & Set 1 & Set 2 & Set 3 & Set 4 & Set 5 \\
\hline A) Heiden & 5 & 8 & & & & & \\
\hline B1) Rack Pull & 5 & 5 & & & & & \\
\hline $\begin{array}{c}\text { B2) Tall Kneeling } \\
\text { Band Alphabet }\end{array}$ & 2 & 1 & & & & & \\
\hline C1) Renegade Row & 5 & 5 & & & & & \\
\hline $\begin{array}{c}\text { C2) Split Squat with } \\
\text { Anti Rotation Press }\end{array}$ & 3 & $8 /$ & & & & & \\
\hline $\begin{array}{c}\text { D1) Dumb Bell } \\
\text { Incline Press }\end{array}$ & 5 & 5 & & & & & \\
\hline D2) Lateral Step Up & 3 & 10 & & & & & \\
\hline
\end{tabular}

\section{Appendix 2: Video Links for Exercises}

\begin{tabular}{|c|c|}
\hline Exercise & $\begin{array}{l}\text { Type phrase below in YouTube Search } \\
\text { box. Video should be top video in list! }\end{array}$ \\
\hline \multicolumn{2}{|l|}{ Phase 1} \\
\hline \multicolumn{2}{|l|}{ Dynamic Warm-up } \\
\hline $\begin{array}{l}\text { Kneeling rectus femoris stretch/couch } \\
\text { stretch }\end{array}$ & UOI couch stretch \\
\hline Kneeling split stance hip adductor stretch & UOI kneeling hip adductor stretch \\
\hline Bear crawls & UOI bear crawl \\
\hline 1 leg SLDL walk & UOI SLDL walk \\
\hline $\begin{array}{l}\text { Lunge walk, } 3 \text { pt extension, thoracic } \\
\text { rotation }\end{array}$ & UOI lunge 3 ptext \\
\hline Prayer lats stretch w/exhale & UOI prayer lats stretch \\
\hline Forearm Wall Slides “Y's" & UOI wall slide 1 , UOI wall slide 2 \\
\hline \multicolumn{2}{|l|}{ Training (Day 1) } \\
\hline Medicine Ball Overhead Slam & UOI med ball overhead slam \\
\hline Kettlebell Deadlift & Great kettlebell exercise for legs and back \\
\hline Single Arm Cable Row & Cressey standing 1-arm cable row \\
\hline Single Leg Hip Thrust from Box & Resilient bench supported single leg \\
\hline Quadruped T and Y & $\begin{array}{l}\text { Haverford quadruped } \mathrm{Y} \text { and } \mathrm{T}\left(\mathbf{2}^{\text {nd }} \text { video }\right. \\
\text { from top) }\end{array}$ \\
\hline Band Assisted Pull Up & Crossfit band assisted pull-up \\
\hline Anti Rotation Press & Doherty cable anti-rotation press \\
\hline \multicolumn{2}{|l|}{ Training (Day 2) } \\
\hline Box Jump & Herman box jump \\
\hline Goblet Squat & Herman goblet squat \\
\hline Core Activated Dead Bug & Robertson core engaged dead bugs \\
\hline Push Up, Yoga Variation & Cressey arm care lesson 4 \\
\hline
\end{tabular}


Citation: DeFroda SF, Staffa SJ, Dubuque T, Bien D, Demers C, et al. (2020) Effect of a 12-Week Off-Season Strength Training Program on Athletic Performance in Adolescent Baseball Players. Sport Med Inj Care 2: 009.

\begin{tabular}{|l|l|}
\hline Band Pull Apart Series & Cressey band pullapart \\
\hline Split Squat & Herman split squat \\
\hline Suit Case Carries & Testosterone kettlebell suitcase \\
\hline Sled Push & Mind pump sled push \\
\hline Training (Day 3) & \\
\hline 25-yard sprint & 25 yard sprint buildup \\
\hline Cable Pull Through & Martinez cable pull throughs \\
\hline Bear Plank with Shoulder Tap & Fisher quadruped plank bear \\
\hline Goblet Loaded Lateral Lunge & Cressey dumbbell goblet \\
\hline Alternating Dumbbell Floor Press & Herman dumbbell floor \\
\hline Single Leg RDL & Testosterone single leg Romanian \\
\hline Contralaterally loaded Step Up & Cutler contralateral step up \\
\hline
\end{tabular}

\section{Video Links for Exercises}

\begin{tabular}{|c|c|}
\hline Exercise & $\begin{array}{l}\text { Type phrase below in YouTube Search } \\
\text { box. Video should be top video in list! }\end{array}$ \\
\hline \multicolumn{2}{|l|}{ Phase 2} \\
\hline \multicolumn{2}{|l|}{ Dynamic Warmup } \\
\hline $\begin{array}{l}\text { Kneeling rectus femoris stretch/couch } \\
\text { stretch }\end{array}$ & UOI couch stretch \\
\hline Kneeling split stance hip adductor stretch & UOI kneeling hip adductor stretch \\
\hline Bear crawls & UOI bear crawl \\
\hline 1 leg SLDL walk & UOI SLDL walk \\
\hline $\begin{array}{l}\text { Lunge walk, } 3 \mathrm{pt} \text { extension, thoracic } \\
\text { rotation }\end{array}$ & UOI lunge 3 ptext \\
\hline Prayer lats stretch w/exhale & UOI prayer lats stretch \\
\hline Forearm Wall Slides "Y's" & UOI wall slide 1 , UOI wall slide 2 \\
\hline \multicolumn{2}{|l|}{ Training (Day 1) } \\
\hline $\begin{array}{l}\text { Medicine Ball Kneeling Chest Pass/Hip } \\
\text { Hinge }\end{array}$ & MB chest pass tall kneel w hinge \\
\hline Trap Bar Deadlift & How to Beast trap bar deadlift \\
\hline Bottoms Up Kettlebell Press & Cressey bottoms up KB military \\
\hline Pull Up & Herman pull up 3 golden rules \\
\hline Side Plank with Row & Momentum side plank cable row \\
\hline Single Leg RDL with Cable & Bodysmith low cable single \\
\hline ESD Battle Ropes Circuit & Criticalbench battle ropes circuit \\
\hline \multicolumn{2}{|l|}{ Training (Day 2) } \\
\hline Kettlebell Swing & Men's Health kettlebell swing \\
\hline Bilateral Kettlebell Racked Squat & Filly dual KB rack squat \\
\hline Stir the Pot & Testosterone stir the pot \\
\hline Landmine Press & Cressey landmine press \\
\hline Band Step Back@90/90 & (no video available) \\
\hline Rear Foot Elevated Split Squat & Resilient RFESS \\
\hline Half Kneeling Cable Chop & $\begin{array}{l}\text { Cressey half kneeling cable chop( } 2 \text { ndfr } \\
\text { top) }\end{array}$ \\
\hline Lateral Sled Drag & Resilient lateral sled drag \\
\hline \multicolumn{2}{|l|}{ Training (Day 3) } \\
\hline Bench Straddle Hop & Resilient bench straddle hop \\
\hline Cable Alternating Row & Tier 1 single arm alternating \\
\hline Hamstring Curl with Ball & Beier swiss ball hamstring \\
\hline Inverted Row & Cressey pronated grip \\
\hline Bench Side Plank & Resilient bench side plank ( $\mathbf{2}^{\text {nd }}$ fr top) \\
\hline
\end{tabular}

\begin{tabular}{|l|l|}
\hline Leg Press & Instructional fitness seated leg press \\
\hline ESD Bike Interval Circuit & Body Coach HIIT exercise bike \\
\hline
\end{tabular}

\section{Video Links for Exercises}

\begin{tabular}{|c|c|}
\hline Exercise & $\begin{array}{l}\text { Type phrase below in YouTube Search } \\
\text { box. Video should be top video in list! }\end{array}$ \\
\hline \multicolumn{2}{|l|}{ Phase 3} \\
\hline \multicolumn{2}{|l|}{ Dynamic Warmup } \\
\hline $\begin{array}{l}\text { Kneeling rectus femoris stretch/couch } \\
\text { stretch }\end{array}$ & UOI couch stretch \\
\hline Kneeling split stance hip adductor stretch & UOI kneeling hip adductor stretch \\
\hline Bear crawls & UOI bear crawl \\
\hline 1 leg SLDL walk & UOI SLDL walk \\
\hline $\begin{array}{l}\text { Lunge walk, } 3 \text { pt extension, thoracic } \\
\text { rotation }\end{array}$ & UOI lunge 3 ptext \\
\hline Prayer lats stretch w/exhale & UOI prayer lats stretch \\
\hline Forearm Wall Slides "Y's" & UOI wall slide 1 , UOI wall slide 2 \\
\hline \multicolumn{2}{|l|}{ Training (Day 1) } \\
\hline Medicine Ball Crow Hop to Shot Put & Warbird medicine ball crowhop \\
\hline Landmine Single Leg RDL & Filly Landmine Single Leg \\
\hline Suspension Trainer Fall Out & Unified suspension trainer \\
\hline Step Up & Men's Health stepup( $\mathbf{2}^{\text {nd }}$ from top $)$ \\
\hline Cable Row to $90 / 90$ ER & (no video available) \\
\hline Single Arm Cable Pull Down & Cressey half-kneeling 1-arm lat \\
\hline Split Stance Chop & HighPerformance split stance high to low \\
\hline $\begin{array}{l}\text { ESD Speed Ladder Frontal Plane } \\
\text { Emphasis }\end{array}$ & Forefront frontal plane agility \\
\hline \multicolumn{2}{|l|}{ Training (Day 2) } \\
\hline Medicine Ball Side Throw & Cressey rotational medicine ball shotput \\
\hline Reverse Lunge & Resilient reverse lunge \\
\hline Side Plank with Clam & Reinold side plank clam exercise \\
\hline Turkish Get Up & Kettlebell kings turkish get up \\
\hline $\mathrm{X}$ Band Walk & Coach Will $\mathrm{X}$ band walk \\
\hline Suspension Trainer Assisted Bowler Squat & Rippel suspension trainer bowler \\
\hline Landmine Row & Herman how to $t$ bar row ( $2^{\text {nd }}$ from top) \\
\hline $\begin{array}{l}\text { ESD Speed Ladder with Sagittal Plane } \\
\text { Emphasis }\end{array}$ & Forefront sagittal plane agility \\
\hline \multicolumn{2}{|l|}{ Training (Day 3) } \\
\hline Heiden & High Performance Heidens ( $\mathbf{2}^{\text {nd }}$ from top) \\
\hline Rack Pull & Herman rack pull \\
\hline Tall Kneeling Band Alphabet & Gibbons tall kneeling paloff \\
\hline Renegade Row & Strength camp renegade row \\
\hline Split Squat with Anti Rotation Press & Split Squat Pos Anti-Rotational Press \\
\hline Dumbbell Incline Press & Herman dumbbell incline press \\
\hline Lateral Step Up & Petersen goblet lateral step up \\
\hline
\end{tabular}

\section{References}

1. Pasulka J, Jayanthi N, McCann A, Dugas LR, LaBella C, et al. (2017) Specialization patterns across various youth sports and relationship to injury risk. Phys Sportsmed 45: 344-352.

2. Faigenbaum AD, Rial T, Peña J, Chulvi-Medrano I (2019) Journal of Science in Sport and Exer et al. Resistance Exercise for the Prevention and Treatment of Pediatric Dynapenia. J Sci Sport Exerc 1: 208-216. 
Citation: DeFroda SF, Staffa SJ, Dubuque T, Bien D, Demers C, et al. (2020) Effect of a 12-Week Off-Season Strength Training Program on Athletic Performance in Adolescent Baseball Players. Sport Med Inj Care 2: 009.

3. Faigenbaum A, Lloyd R, MacDonald J MG, Myer GD (2016) Citius,Altius, Fortius: beneficial effects of resistance training for young athletes: narrative review. Br J Sports Med 50: 3-7.

4. Faigenbaum A, McDonald JP, Haff GG (2019) Are young athletes strong enough for sport? DREAM On. Curr Sports Med Rep 18: 6-8.

5. Szymanski DJ, Szymanski JM, Bradford TJ, Schade RL, Pascoeet DD, et al. (2007) Effect of twelve weeks of medicine ball training on high school baseball players. J strength Cond Res 21: 894-901.

6. Szymanski DJ, Szymanski JM, Schade RL, Bradford TJ, McIntyre JS, et al. (2010) The relation between anthropometric and physiological variables and bat velocity of high-school baseball players before and after 12 weeks of training. J strength Cond Res 24: 2933-2943.

7. Reinold MM, Macrina LC, Fleisig GS, Aune K, Andrews JR, et al. (2018) Effect of a 6-Week Weighted Baseball Throwing Program on Pitch Velocity, Pitching Arm Biomechanics, Passive Range of Motion, and Injury Rates. Sports Health 10: 327-333.

8. Escamilla RF, Fleisig GS, Yamashiro K, Mikla T, Dunning R, et al. (2010) Effects of a 4-week youth baseball conditioning program on throwing velocity. J strength Cond Res 24: 3247-3254.

9. Boyle M (2003) Functional Training in Sports. 1st ed. Champaign, IL: Human Kinetics, 2003.
10. Cressey E, Fitzgerald M (2008)Maximum Strength. 1st ed. Philadelphia, PA: DeCapo Press, 2008.

11. Joyce D, Lewindon D (2014) High Performance Training For Sports. Champaign, IL: Human Kinetics, 2014.

12. Jones MT, Matthews TD, Murray M, Raalte JV, Jensen BE, et al. (2010) Psychological correlates of performance in female athletes during a 12week off-season strength and conditioning program. J strength Cond Res 24: 619-628.

13. Escamilla RF, Ionno M, deMahy MS, Fleisig GS,Wilk KE, et al. (2012) Comparison of Three Baseball-Specific 6-Week Training Programs on Throwing Velocity in High School Baseball Players. J Strength Cond Res 26: $1767-1781$

14. Cressey E. In-Season Baseball Strength and Conditioning: Part 1.

15. Cressey E. In-Season Baseball Strength and Conditioning: Part 2- High School Baseball.

16. Brechue WF, Mayhew JL, Piper FC (2005) Equipment and running surface alter sprint performance of college football players. J Strength Cond Res 19: 821-825. 


\section{H}

Advances In Industrial Biotechnology | ISSN: 2639-5665

Advances In Microbiology Research | ISSN: 2689-694X

Archives Of Surgery And Surgical Education | ISSN: 2689-3126

Archives Of Urology

Archives Of Zoological Studies | ISSN: 2640-7779

Current Trends Medical And Biological Engineering

International Journal Of Case Reports And Therapeutic Studies | ISSN: 2689-310X

Journal Of Addiction \& Addictive Disorders | ISSN: 2578-7276

Journal Of Agronomy \& Agricultural Science | ISSN: 2689-8292

Journal Of AIDS Clinical Research \& STDs | ISSN: 2572-7370

Journal Of Alcoholism Drug Abuse \& Substance Dependence | ISSN: 2572-9594

Journal Of Allergy Disorders \& Therapy | ISSN: 2470-749X

Journal Of Alternative Complementary \& Integrative Medicine | ISSN: 2470-7562

Journal Of Alzheimers \& Neurodegenerative Diseases | ISSN: 2572-9608

Journal Of Anesthesia \& Clinical Care | ISSN: 2378-8879

Journal Of Angiology \& Vascular Surgery | ISSN: 2572-7397

Journal Of Animal Research \& Veterinary Science | ISSN: 2639-375

Journal Of Aquaculture \& Fisheries | ISSN: 2576-5523

Journal Of Atmospheric \& Earth Sciences | ISSN: 2689-8780

Journal Of Biotech Research \& Biochemistry

Journal Of Brain \& Neuroscience Research

Journal Of Cancer Biology \& Treatment | ISSN: 2470-7546

Journal Of Cardiology Study \& Research | ISSN: 2640-768X

Journal Of Cell Biology \& Cell Metabolism | ISSN: 2381-1943

Journal Of Clinical Dermatology \& Therapy | ISSN: 2378-8771

Journal Of Clinical Immunology \& Immunotherapy | ISSN: 2378-8844

Journal Of Clinical Studies \& Medical Case Reports | ISSN: 2378-880

Journal Of Community Medicine \& Public Health Care | ISSN: 2381-1978

Journal Of Cytology \& Tissue Biology | ISSN: 2378-9107

Journal Of Dairy Research \& Technology | ISSN: 2688-9315

Journal Of Dentistry Oral Health \& Cosmesis | ISSN: 2473-6783

Journal Of Diabetes \& Metabolic Disorders | ISSN: 2381-201X

Journal Of Emergency Medicine Trauma \& Surgical Care | ISSN: 2378-8798

Journal Of Environmental Science Current Research | ISSN: 2643-5020

Journal Of Food Science \& Nutrition | ISSN: 2470-1076

Journal Of Forensic Legal \& Investigative Sciences | ISSN: 2473-733X

Journal Of Gastroenterology \& Hepatology Research | ISSN: 2574-2566
Journal Of Genetics \& Genomic Sciences | ISSN: 2574-2485

Journal Of Gerontology \& Geriatric Medicine | ISSN: 2381-8662

Journal Of Hematology Blood Transfusion \& Disorders | ISSN: 2572-2999

Journal Of Hospice \& Palliative Medical Care

Journal Of Human Endocrinology | ISSN: 2572-9640

Journal Of Infectious \& Non Infectious Diseases | ISSN: 2381-8654

Journal Of Internal Medicine \& Primary Healthcare | ISSN: 2574-2493

Journal Of Light \& Laser Current Trends

Journal Of Medicine Study \& Research | ISSN: 2639-5657

Journal Of Modern Chemical Sciences

Journal Of Nanotechnology Nanomedicine \& Nanobiotechnology | ISSN: 2381-2044

Journal Of Neonatology \& Clinical Pediatrics | ISSN: 2378-878X

Journal Of Nephrology \& Renal Therapy | ISSN: 2473-7313

Journal Of Non Invasive Vascular Investigation | ISSN: 2572-7400

Journal Of Nuclear Medicine Radiology \& Radiation Therapy | ISSN: 2572-7419

Journal Of Obesity \& Weight Loss | ISSN: 2473-7372

Journal Of Ophthalmology \& Clinical Research | ISSN: 2378-8887

Journal Of Orthopedic Research \& Physiotherapy | ISSN: 2381-2052

Journal Of Otolaryngology Head \& Neck Surgery | ISSN: 2573-010X

Journal Of Pathology Clinical \& Medical Research

Journal Of Pharmacology Pharmaceutics \& Pharmacovigilance | ISSN: 2639-5649

Journal Of Physical Medicine Rehabilitation \& Disabilities | ISSN: 2381-8670

Journal Of Plant Science Current Research | ISSN: 2639-3743

Journal Of Practical \& Professional Nursing | ISSN: 2639-568

Journal Of Protein Research \& Bioinformatics

Journal Of Psychiatry Depression \& Anxiety | ISSN: 2573-0150

Journal Of Pulmonary Medicine \& Respiratory Research | ISSN: 2573-0177

Journal Of Reproductive Medicine Gynaecology \& Obstetrics | ISSN: 2574-2574

Journal Of Stem Cells Research Development \& Therapy | ISSN: 2381-2060

Journal Of Surgery Current Trends \& Innovations | ISSN: 2578-7284

Journal Of Toxicology Current Research | ISSN: 2639-3735

Journal Of Translational Science And Research

Journal Of Vaccines Research \& Vaccination | ISSN: 2573-0193

Journal Of Virology \& Antivirals

Sports Medicine And Injury Care Journal | ISSN: 2689-8829

Trends In Anatomy \& Physiology | ISSN: 2640-7752

Submit Your Manuscript: https://www.heraldopenaccess.us/submit-manuscript 